\title{
USAHA PEMASARAN PRODUSEN TEMPE
}

\author{
R. Nana Kusdiana; Trias Septyoari Putranto
}

Hotel Management Department, Faculty of Economic and Communication, BINUS University

Jln. K.H. Syahdan No. 9, Palmerah, Jakarta Barat 11480

rkusdiana@binus.edu; tputranto@binus.edu

\begin{abstract}
Tempe is a food made from the fermentation of soybeans or some other materials using somekind of fungus Rhizopus, such as Rhizopus oligosporus, Rh. oryzae, Rh. stolonifer or also known as bread mold, or Rh. arrhizus. Fermentation preparations are commonly known as "yeast tempe". Tempe has been known since ancient times, particularly in Java as supplement staple food which is high protein and low cholesterol. Tempe and tofu selling price is still low compared to other protein food sources, such as fish and chicken. According to market research, the majority of tempe and tofu products is still the lower class' consumption, since the quality and processing methods are traditional distribution, including in sanitation and hygiene. It is necessary to stimulate and generate interest in the bank to develop relationship with the Indonesian Tofu Tempe Producers Cooperative (KOPTI) and its members to tempe producers can increase production and performance. Tempe and Tofu Development Centers Manufacturers through Integrated Partnership Program by KOPTI as a company with a core group of tempe and tofu manufacturers, which are members of the KOPTI, is the modernization of tempe and tofu small business activity to be an independent food business industry.
\end{abstract}

Keywords: tempe, Indonesian traditional food, marketing

\begin{abstract}
ABSTRAK
Tempe adalah makanan yang dibuat dari fermentasi terhadap biji kedelai atau beberapa bahan lain yang menggunakan beberapa jenis kapang Rhizopus, seperti Rhizopus oligosporus, Rh. oryzae, Rh. stolonifer atau disebut juga kapang roti, atau Rh. arrhizus. Sediaan fermentasi ini secara umum dikenal sebagai "ragi tempe". Tempe/tahu yang dikenal sejak zaman dahulu, terutama di Pulau Jawa adalam makanan pelengkap makanan pokok berupa makanan sumber protein tinggi yang rendah kolesterol. Harga jual tempe dan tahu masih rendah dibandingkan dengan makanan sumber protein lainya, misalnya ikan dan daging ayam. Menurut penelitian pasar, sebagian besar produk tempe dan tahu masih merupakan konsumsi masyarakat kelah bawah, karena kualitas dan cara pengolahan serta penyalurannya masih tradisional, termasuk dalam sanitasi dan higienitasnya. Diperlukan upaya memacu dan membangkitkan minat bank untuk mengembangkan hubungan dengan Koperasi Produsen Tempe Tahu Indonesia (KOPTI) dan anggotanya agar pengrajin tempe dapat meningkatkan produksi dan kinerjanya. Pengembangan Sentra Produsen Tempe Tahu melalui Program Kemitraan Terpadu oleh KOPTI sebagai perusahaan inti dengan kelompok pengrajin tempe tahu, yaitu para anggota KOPTI adalah kegiatan modernisasi usaha kecil tempe dan tahu menjadi usaha industri makanan mandiri.
\end{abstract}

Kata kunci: tempe, makanan tradisional Indonesia, pemasaran 


\section{PENDAHULUAN}

\section{Tujuan Model Kelayakan}

Diperlukan upaya memacu dan membangkitkan minat bank untuk mengembangkan hubungan dengan Koperasi Produsen Tempe Tahu Indonesia (KOPTI) dan anggotanya, yaitu para pengrajin/produsen tempe dan tahu melalui pemberian kredit berjangka untuk membangun Sentra Produsen Tempe Tahu (Sentra) yang akan menjadi tempat produksi untuk kelompok kelompok pengrajin. Pengembangan Sentra dilaksanakan melalui Program Kemitraan Terpadu (PKT) antara kelompok pengrajin dengan KOPTI.

Tujuan dari kredit yang dibutuhkan oleh para anggota Sentra adalah untuk modernisasi, ekspansi, maupun relokasi usaha tempe dan tahu yang dimiliki anggota KOPTI yang telah bekerja sama dalam kelompok di suatu tempat tertentu. Kredit Usaha kecil yang diberikan bank kepada suatu Sentra biasanaya untuk membiayai bangunan, yaitu gudang, ruang produksi, rumah tinggal, alat produksi dan alat pengangkutan bahan baku maupun hasil produksi. Prasarana yang dapat dibiayai adalah jalan, pagar, saluran air bersih, saluran listrik, serta alat pengelolaan limbah. Meskipun beberapa bank telah mempunyai nasabah di subsektor industri kecil tempe dan tahu dan juga memberikan kredit kepada KOPTI sampai sekarang para pengrajin tempe dan tahu belum menjadi sasaran pasar perbankan. Potensi pemberiankredit kepada kelompok pengrajin tempe dan tahu cukup besar, karena beberapa KOPTI termasuk anggotanya hanya menerima kredit dari bank dengan jumlah sedikit dan masihmempunyai potensi untuk menggunakan kredit produktif secara aman, KOPTI maupun anggotanya sekaligus memiliki modal sendiri, usahanya sudah lama beroperasi secara layak dan menguntungkan. Menurut informasi dari bank yang telah membiayai KOPTI maupun usaha anggotanya portofolio kredit tersebut pada umumnya lancar dan menguntungkan bagi bank maupun para nasabah.

\section{Prospek dan Kendala}

Tempe/tahu yang dikenal sejak dahulu, terutama di Pulau Jawa adalah makanan pelengkap makanan pokok berupa makanan sumber protein tinggi yang rendah kolesterol. Harga jual tempe dan tahu masih rendah berbanding dengan makanan sumber protein lainya, misalnya ikan dan daging ayam. Menurut penelitian pasar, sebagian besar produk tempe dan tahu masih merupakan konsumsi masyarakat kelas bawah, karena kualitas dan cara pengolahan serta penyalurannya masih tradisional, termasuk dalam sanitasi dan higienitas. Sebagian besar dari para pengrajin tempe berasal dari Malang, Ngawi, Kediri, Purwokerto, Pekalongan. Para pengrajin tahu biasanya berasal dari Sumedang danTasikmalaya. Usaha kecil tempe dan tahu bersifat industri rumah tangga, dengan pemilik dan tenaga kerjanya masih mempunyai hubungan keluarga. Cara produksi masih tradisional dengan menggunakan alat produksi sederhana, yang sebagian dibuat oleh para pengrajin maupun oleh bengkel kecil. Hampir semua pengrajin tempe dan tahu tergabung dalam koperasi primer yaitu KOPTI. Pembinaan KOPTI maupun anggotanya dilakukan oleh Kantor Depkop \& PPK serta Kantor Deperindag Tingkat II. Sebagian besar dari kebutuhan bahan baku berupa kedelai impor oleh BULOG sebagai importir tunggal di RI. Sekitar 30\% dari kebutuhan kedelai di Indonesia adalah impor dari luar negeri. Masing-masing KOPTI diberi kuota oleh BULOG/DOLOG antara 30\% s.d. 50\% dari jumlah kebutuhan kedelai. Kekurangan dibeli KOPTI maupun anggotanya di pasar umum.

Khusus untuk DKI Jakarta maupun di Kotamadya lainnya para pengrajin tempe dan tahu mengalami masalah berkaitan dengan lokasi usahanya yang saat ini tersebar di daerah pemukiman masyarakat menengah dan bawah. Masalah timbul pada saat digusur dari tempat produksi yang tidak resmi, oleh instansi Pemda. Biaya investasi untuk tempat produksi dan rumah tinggal untuk pengrajin tempe dan tahu di kota besar dirasa terlalu tinggi oleh pengrajin. 
Limbah dari proses produksi khususnya limbah produksi tahu merupakan faktor negatif yang dapat mencemarkan lingkungan di daerah pemukiman tersebut.Dengan tingkat pendidikan dan kesadaran pengrajin tempe dan tahu yang masih relatif rendah, para pengrajin belum dapat mengungkapkan kebutuhannya kepada instansi berwenang. Aparat Pemda pada umumnya tidak memberikan prioritas kepada kebutuhan para pengrajin tempe dan tahu. Sifat para pengrajin untuk memakai laba yang diperoleh (simpanan) dari usahanya untuk membangun rumah mewah dan membeli tanah di kampung halaman merupakan suatu unsur yang tidak produktif dan dapat menghambat pengembangan usaha tempe dan tahu serta kualitas hidup para pengrajin serta keluarganya di kota besar. Pada sepuluh tahun terakhir sampai saat ini unsur subsidi harga jual kedelai dari BULOG kepada KOPTI makin menurun dan dianggap akan dihentikan, nampaknya monopoli impor kedelai oleh Bulog akan diregulasi.Masalah tersebut diatas merupakan ancaman yang harus diatasi berkaitan dengan pengembangan Sentra Produsen Tempe dan tahu melalui kerja sama KOPTI kelompok anggotanya serta Bank pemberi kredit.

Kekuatan para pengrajin tempe dan tahu dapatdisimpulkan sebagai berikut: (1) pengrajin tempe tidak kena persaingan dari produsen besar, begitu juga para pengrajin tahu tidak merasa adanya saingan terlalu berat dari produsen besar. (2) Kebutuhan modal kerja sera biaya investasi alat produksi relatif rendah dan merupakan modal sendiri bagi para pengrajin. (3) Beberapa KOPTI sudah memiliki tanah yang letaknya strategis dan cukup luas di wilayah kerja yang dapat memenuhi sebagian besar atau seluruh kebutuhan tanah Sentra PTT berkaitan dengan relokasi dan modernisasi usaha tempe dan tahu. (4) Pembentukan kelompok oleh para pengrajin anggota KOPTI sudah lama berjalan. Hubungan kerja maupun sosial antara anggota kelompok baik dan kuat karena para pengrajin biasanya berasal dari daerah yang sama. Peranan KOPTI yang menunjukkan kinerja tinggi dirasakan manfaatnya oleh para anggota kelompok.

\section{Sentra Produsen}

Tujuan PKT sentra Produsen Tempe dan tahu antara KOPTI dengan kelompok pengrajin tempe dan tahu untuk meningkatkan produksi dan kinerja UK produsen tempe dan tahu, supaya UK tersebut menjadi layak untuk dibiayai dengan KUK secara aman. Para pengrajin tempe dan tahu tidak bermitra dengan Usaha Besar melalui KOPTI selain BULOG/DOLOG. BULOG adalah BUMN dengan tujuan utama untuk menstabilkan harga serta persediaan bahan makanan pokok di seluruh pelosok tanah air. Dalam Model KPKT ini, BULOG berfungsi sebagai UB yang memasok sebagian dari kebutuhan kedelai kepada KOPTI dan anggotanya dengan harga yang masih menguntungkan baik untuk KOPTI maupun untuk BULOG sendiri. BULOG tidak menjadi pihak yang terlibat langsung dalam Nota Kesepakatan Sentra Produsen Tempe dan tahu. Tim penyusun Model PKT menganggap KOPTI mampu berfungsi sebagai pengembang Sentra Produsen Tempe dan sebagian besar dari 144 KOPTI memiliki tanah yang dapat menjadi lokasi Sentra PTT untuk kelompok anggotanya. PKT Sentra Produsen Tempe adalah program kemitraan antara KOPTI dengan kelompok anggotanya, KOPTI membangun sarana dan prasarana produksi untuk satu atau lebih kelompok anggotanya atas satu bidang tanah disebut Sentra Produksi Tempe. Satu pengrajin tempe dan tahu yang telah menjadi anggota kelompok dapat menyewa atau membeli strata atau satu ruang produksi di Sentra tersebut. Ada beberapa manfaat untuk KOPTI yang dapat diperoleh dari pengembangan Sentra tersebut. KOPTI dapat menerima sewa atas tanah dengan pola Strata atau menerima sewa Ruang Produksi melalui pola menyewa ruang di Sentra PTT. Pengembangan dan pengelolaan Sentra dapat menjadi bisnis baru atau profit center bagi KOPTI. Kalau KOPTI secara aktif ikut serta sebagai pengembang sarana dan prasarana produksi untuk kelompok pengrajin melalui Sentra PTT, KOPTI dapat juga membeli alat untuk mengelola limbah dari produsen yang ada di Sentra tersebut. Limbah yang diolah oleh KOPTI dijual kepada produsen pakan ternak, dan kegiatan pengelolaan limbah merupakan profit center baru untuk KOPTI. 


\section{Kemitraan Terpadu}

\section{Organisasi}

Proyek Kemitraan Terpadu (PKT) adalah suatu program kemitraan terpadu yang melibatkan usaha besar (inti), usaha kecil (plasma) dengan melibatkan bank sebagai pemberi kredit dalam suatu ikatan kerja sama yang dituangkan dalam nota kesepakatan. Tujuan PKT antara lain adalah untuk meningkatkan kelayakan plasma, meningkatkan keterkaitan dan kerja sama yang saling menguntungkan antara inti dan plasma, serta membantu bank dalam meningkatkan kredit usaha kecil secara lebih aman dan efisien. Dalam melakukan kemitraan hubungan kemitraan, perusahaan inti (Industri Pengolahan atau Eksportir) dan petani plasma/usaha kecil mempunyai kedudukan hukum yang setara. Kemitraan dilaksanakan dengan disertai pembinaan oleh perusahaan inti, dimulai dari penyediaan sarana produksi, bimbingan teknis, dan pemasaran hasil produksi. Proyek Kemitraan Terpadu ini merupakan kerja sama kemitraan dalam bidang usaha melibatkan tiga unsur, yaitu (1) Petani/Kelompok Tani atau usaha kecil, (2) Pengusaha Besar atau eksportir, dan (3) Bank pemberi KKPA. Masing-masing pihak memiliki peranan di dalam PKT yang sesuai dengan bidang usahanya. Hubungan kerja sama antara kelompok petani/usaha kecil dengan Pengusaha Pengolahan atau eksportir dalam PKT, dibuat seperti halnya hubungan antara Plasma dengan Inti di dalam Pola Perusahaan Inti Rakyat (PIR). Petani/usaha kecil merupakan plasma dan Perusahaan Pengelolaan/Eksportir sebagai Inti. Kerja sama kemitraan ini kemudian menjadi terpadu dengan keikutsertaan pihak bank yang memberi bantuan pinjaman bagi pembiayaan usaha petani plasma. Proyek ini kemudian dikenal sebagai PKT yang disiapkan dengan mendasarkan pada adanya saling berkepentingan di antara semua pihak yang bermitra.

\section{Petani Plasma}

Sesuai keperluan, petani yang dapat ikut dalam proyek ini bisa terdiri atas (a) petani yang akan menggunakan lahan usaha pertaniannya untuk penanaman dan perkebunan atau usaha kecil lain, (b) petani /usaha kecil yang telah memiliki usaha tetapi dalam keadaan yang perlu ditingkatkan dalam untuk itu memerlukan bantuan modal.Untuk kelompok (a), kegiatan proyek dimulai dari penyiapan lahan dan penanaman atau penyiapan usaha, sedangkan untuk kelompok (b), kegiatan dimulai dari telah adanyakebun atau usaha yang berjalan, dalam batas masih bisa ditingkatkan produktivitasnya dengan perbaikan pada aspek usaha.

Luas lahan atau skala usaha bisa bervariasi sesuai luasan atau skala yang dimiliki oleh masingmasing petani/usaha kecil. Pada setiap kelompok tani/kelompok usaha, ditunjuk seorang Ketua dan Sekretaris merangkap Bendahara. Tugas Ketua dan Sekretaris Kelompok adalah mengadakan koordinasi untuk pelaksanaan kegiatan yang harusdilakukan oleh para petani anggotanya, di dalam mengadakan hubungan dengan pihak koperasi dan instansi lainnya yang perlu, sesuai hasil kesepakatan anggota. Ketua kelompok wajib menyelenggarakan pertemuan kelompok secara rutin yang waktunya ditentukan berdasarkan kesepakatan kelompok.

\section{Koperasi}

Para petani/usaha kecil plasma sebagai peserta suatu PKT, sebaiknya menjadi anggota suatu koperasi primer di tempatnya. Koperasi bisa melakukan kegiatan-kegiatan untuk membantu plasma di dalam pembangunan kebun/usaha sesuai keperluannya. Fasilitas KKPA hanya bisa diperoleh melalui keanggotaan koperasi. Koperasi yang mengusahakan KKPA harus sudah berbadan hukum dan memiliki kemampuan serta fasilitas yang cukup baik untuk keperluan pengelolaan administrasi pinjaman KKPA para anggotanya. Jika menggunakan skim Kredit Usaha Kecil (KUK), kehadiran koperasi primer tidak merupakan keharusan. 


\section{Perusahaan Besar dan Pengelola/Eksportir}

Suatu Perusahaan dan Pengelola/Eksportir yang bersedia menjalin kerja sama sebagai inti dalam Proyek Kemitraan terpadu ini, harus memiliki kemampuan dan fasilitas pengolahan untuk bisa melakukan ekspor, serta bersedia membeli seluruh produksi dari plasma untuk selanjutnya diolah di pabrik dan atau diekspor. Di samping ini, perusahaan inti perlu memberikan bimbingan teknis usaha dan membantu dalam pengadaan sarana produksi untuk keperluan petani plasma/usaha kecil. Apabila Perusahaan Mitra tidak memiliki kemampuan cukup untuk mengadakan pembinaan teknis usaha, PKT tetap akan bisa dikembangkan dengan sekurang-kurangnya pihak Inti memiliki fasilitas pengolahan untuk diekspor. Hal ini penting untuk memastikan adanya pemasaran bagi produksi petani atau plasma. Meskipun demikian petani plasma/usaha kecil dimungkinkan untuk mengolah hasil panennya, yang kemudianharus dijual kepada Perusahaan Inti. Dalam hal perusahaan inti tidak bisa melakukan pembinaan teknis, kegiatan pembibingan harus dapat diadakan oleh Koperasi dengan memanfaatkan bantuan tenaga pihak DinasPerkebunan atau lainnya yang dikoordinasikan oleh Koperasi. Apabila koperasi menggunakan tenaga Penyuluh Pertanian Lapangan (PPL), perlu mendapatkan persetujuan Dinas Perkebunan setempat dan koperasi memberikan bantuan biaya yangdiperlukan.Koperasi juga bisa memperkerjakan langsung tenaga-tenaga teknis yang memiliki keterampilan di bidang perkebunan/usaha untuk membimbing petani/usaha kecil dengan dibiayai sendiri oleh Koperasi. Tenaga-tenaga ini bisa diberi honorarium oleh Koperasi yang bisa kemudian dibebankan kepada petani, dari hasil penjualan secara proposionalmenurut besarnya produksi. Sehingga makin tinggi produksi kebun petani/usaha kecil, akan semakin besar pula honor yang diterimanya.

\section{Bank}

Bank berdasarkan adanya kelayakan usaha dalam kemitraan antara pihak Petani Plasma dengan Perusahaan Perkebunan dan Pengolahan/Eksportir sebagai inti, dapat kemudian melibatkan diri untuk biaya investasi dan modal kerja pembangunan atau perbaikan kebun. Di samping mengadakan pengamatan terhadap kelayakan aspek-aspek budidaya/produksiyang diperlukan, termasuk kelayakan keuangan. Pihak bank di dalam mengadakan evaluasi, juga harus memastikan bagaimana pengelolaan kredit dan persyaratan lain yang diperlukan sehingga dapat menunjang keberhasilan proyek. Skim kredit yang akan digunakan untuk pembiayaan ini, bisa dipilih berdasarkan besarnya tingkat bunga yang sesuai dengan bentuk usaha tani ini, sehingga mengarah pada perolehannya pendapatan bersih petani yang paling besar. Dalam pelaksanaanya, bank harus dapat mengatur cara petani plasma akan mencairkan kredit dan mempergunakannya untuk keperluan operasional lapangan, dan cara petani akan membayar angsuran pengembalian pokok pinjaman beserta bunganya. Untuk ini, bank agar membuat perjanjian kerja sama dengan pihak perusahaan inti, berdasarkan kesepakatan pihak petani/kelompok tani/koperasi. Perusahaan inti akan memotong uanghasil penjualan petani plasma/usaha kecil sejumlah yang disepakati bersama untuk dibayarkan langsung kepada bank. Besarnya potongan disesuaikan dengan rencana angsuran yang telah dibuat pada waktu perjanjian kredit dibuat oleh pihak petani/Kelompok tani/koperasi. Perusahaan inti akan memotong uang hasil penjualan petani plasma/usaha kecil sejumlah yang disepakati bersama untuk dibayarkan langsungkepada Bank. Besarnya potongan disesuaikan dengan rencana angsuran yang telah dibuat pada waktu perjanjian kredit dibuat oleh pihak petani plasma dengan bank.

\section{Pola Kerja Sama}

Untuk kemitraan antara petani/kelompok tani/koperasi dengan perusahaan mitra, dapat dibuat menurut dua pola yaitu: a) Petani yang tergabung dalam kelompok-kelompok tani mengadakan perjanjian kerja sama langsung kepada Perusahaan Perkebunan/Pengolahan Eksportir. Dengan bentuk kerja sama seperti ini, pemberian kredit yang berupa KKPA kepada petani plasma dilakukan dengan kedudukan Koperasi sebagai Channeling Agent, dan pengelolaannya langsung ditangani oleh Kelompok tani. Sedangkan masalah pembinaan harus bisa diberikan oleh Perusahaan Mitra. b) Petani 
yang tergabung dalam kelompok-kelompok tani, melalui koperasinyamengadakan perjanjian yang dibuat antara Koperasi (mewakili anggotanya) dengan perusahaan perkebunan/pengolahan/eksportir. Dalam bentuk kerja sama seperti ini, pemberian KKPA kepada petani plasma dilakukan dengan kedudukan koperasi sebagai Executing Agent. Masalah pembinaan teknis budidaya tanaman/pengelolaan usaha, apabila tidak dapat dilaksanakan oleh pihak Perusahaan Mitra, akan menjadi tanggung jawab koperasi.

\section{Penyiapan Proyek}

Untuk melihat bahwa PKT ini dikembangkan dengan sebaiknya dan dalam proses kegiatannya nanti memperoleh kelancaran dan keberhasilan, minimal dapat dilihat dari bagaimana PKT ini disiapkan. Kalau PKT ini akan mempergunakan KKPA untuk modal usaha plasma, perintisannya dimulai dari: pertama, adanya petani/pengusaha kecil yang telah menjadi anggota koperasi dan lahan pemilikannya akan dijadikan kebun/tempat usaha atau lahan kebun/usahanya sudah ada, tetapi akan ditingkatkan produktivitasnya. Petani/usaha kecil tersebut harus menghimpun diri dalam kelompok dengan anggota sekitar 25 petani/kelompok usaha. Berdasarkan persetujuan bersama, yang didapatkan melalui pertemuan anggotakelompok, mereka bersedia atau berkeinginan untuk bekerja sama dengan perusahaan perkebunan/ pengolahan/eksportir dan bersedia mengajukan permohonan kredit (KKPA) untuk keperluan peningkatan usaha. Kedua, adanya perusahaan perkebunan/pengolahan dan eksportir, yang bersedia menjadi mitra petani/usaha kecil, dan dapat membantu memberikan pembinaan teknik budidaya/produksi serta proses pemasarannya. Ketiga, dipertemukannya kelompok tani/usaha kecil dan pengusaha perkebunan/pengolahandan eksportir tersebut, untuk memperoleh kesepakatan di antara keduanya untuk bermitra. Prakarsa bisa dimulai dari salah satu pihak untuk mengadakan pendekatan, atau ada pihak yang akan membantu sebagai mediator, peran konsultan bisa dimanfaatkan untuk mengadakan identifikasi dan menghubungkan pihak kelompok tani/usaha kecilyang potensial dengan perusahaan yang dipilih memiliki kemampuan tinggi memberikanfasilitas yang diperlukan oleh pihak petani/usaha kecil. Keempat, diperoleh dukungan untuk kemitraan yang melibatkan para anggotanya oleh pihak koperasi. Koperasi harus memiliki kemampuan di dalam mengorganisasikan danmengelola administrasi yang berkaitan dengan PKT ini. Apabila keterampilan koperasi kurang, untuk peningkatannya dapat diharapkan nantinya mendapat pembinaan dari perusahaan mitra. Koperasi kemudian mengadakan langkah-langkah yang berkaitandengan formalitas PKT sesuai fungsinya. Dalam kaitannya dengan penggunaan KKPA, Koperasi harus mendapatkan persetujuan dari para anggotanya, apakah akan beritndak sebagai badan pelaksana (executing agent) atau badan penyalur (channeling agent). Kelima, diperolehnya rekomendasi tentang pengembangan PKT ini oleh pihak instansi pemerintah setempat yang berkaitan (Dinas Perkebunan, Dinas Koperasi, Kantor Badan Pertanahan, dan Pemda). Keenam, lahan yang akan digunakan untuk perkebunan/usaha dalam PKT ini, harus jelas status kepemilikannya bahwa sudah/atau akan bisa diberikan sertifikat dan bukan merupakan lahan yang masih belum jelas statusnya yang benar ditanami/tempat usaha. Untuk itu perlu adanya kejelasan dari pihak Kantor Badan Pertanahan dan pihak Departemen Kehutanan dan Perkebunan.

\section{Mekanisme Proyek}

Mekanisme Proyek Kemitraan Terpadu dapat dilihat pada skema berikut ini: Bank pelaksana akan menilai kelayakan usaha sesuai dengan prinsip-prinsip bank teknis. Jika proyek layak untuk dikembangkan, perlu dibuat suatu nota kesepakatan (Memorandum of Understanding $=$ MoU) yang mengikat hak dan kewajiban masing-masing pihak yang bermitra (inti, Plasma/Koperasi, dan Bank). Sesuai dengan nota kesepakatan, atas kuasa koperasi atau plasma, kredit perbankan dapat dialihkan dari rekening koperasi/plasma ke rekening inti untuk selanjutnya disalurkan ke plasma dalam bentuk sarana produksi, dana pekerjaan fisik, dan lain-lain. Dengan demikian plasma tidak akan menerima uang tunai dari perbankan, tetapi yang diterima adalah sarana produksi pertanian yang penyalurannya dapat melalui inti atau koperasi. Petani plasma melaksanakan proses produksi. Hasil tanaman plasma dijual ke inti dengan harga yangtelah disepakati dalam MoU. Perusahaan inti akan memotong sebagian 
hasil penjualan plasma untuk diserahkankepada bank sebagai angsuran pinjaman dan sisanya dikembalikan ke petani sebagai pendapatan bersih.

\section{Perjanjian Kerja Sama}

Untuk meresmikan kerja sama kemitraan ini, perlu dikukuhkan dalam suatu surat perjanjian kerja sama yang dibuat dan ditandatangani oleh pihak-pihak yang bekerja sama berdasarkan kesepakatan mereka. Dalam perjanjian kerja sama itu dicantumkan kesepakatan apa yang akan menjadi kewajiban dan hak dari masing-masing pihak yang menjalin kerja sama kemitraan itu. Perjanjian tersebut memuat ketentuan yang menyangkut kewajiban pihak Mitra Perusahaan (Inti) dan petani/usaha kecil (plasma) antara lain sebagai berikut: (1) Kewajiban Perusahaan Perkebunan/Pengolahan/Eksportir sebagai mitra (inti): a) memberikan bantuan pembinaan budidaya/produksi dan penaganan hasil; b) membantu petani dalam menyiapkan kebun, pengadaan sarana produksi (bibit, pupuk dan obat-obatan), penanaman serta pemeliharaan kebun/usaha; c) melakukan pengawasan terhadap cara panen dan pengelolaan pasca panen untuk mencapai mutu yang tinggi; d) melakukan pembelian produksi petani plasma; dane. Membantu petani plasma dan bank dalam masalah pelunasan kredit bank (KKPA) dan bunganya, serta bertindak sebagai avalis dalam rangka pemberian kredit bank untuk petani plasma. (2) Kewajiban petani peserta sebagai plasma: a) menyediakan lahan pemilikannya untuk budidaya; b) menghimpun diri secara berkelompok dengan petani tetangganya yang lahan usahanya berdekatan dan sama-sama ditanami; c) melakukan pengawasan terhadap cara panen dan pengelolaan pascapanen untuk mencapai mutu hasil yang diharapkan; d) menggunakan sarana produksi dengan sepenuhnya seperti yang disediakan dalamrencana pada waktu mengajukan permintaan kredit; e) menyediakan sarana produksi lainnya, sesuai rekomendasi budidaya oleh pihak DinasPerkebunan/instansi terkait setempat yang tidak termasuk di dalam rencana waktumengajukan permintaan kredit; f) melaksanakan pemungutan hasil (panen) dan mengadakan perawatan sesuai petunjuk Perusahaan Mitra untuk kemudian seluruh hasil panen dijual kepada Perusahaan Mitra; dan g) pada saat penjualan hasil petani akan menerima pembayaran harga produk sesuai kesepakatan dalam perjanjian dengan terlebih dahulu dipotong sejumlah kewajiban petanimelunasi angsuran kredit bank dan pembayaran bunganya.

\section{Aspek Pemasaran}

\section{Aspek Pemasaran secara Makro}

Data statistik tentang jumlah pengrajin tempe dan tahu akhir 1995 diterima dari Deperindag. Menurut data tersebut, jumlah produsen tempe dan tahu sebanyak 97.254 unit usaha dengan jumlah tenaga kerja termasuk pemilik 284.259 orang. Nilai produksi pada 1995 sekitar Rp.691 milyar. Pada akhir 1996 jumlah PRIMKOPTI di Indonesia sebesar 144 unit koperasi primer. Anggota KOPTI, produsen tempe dan tahu, berjumlah 36.959 orang terdiri dari atas 26.865 anggota produsen tempe dan 10.094 anggota produsen tahu. Berdasarkan informasi dari ketua INKOPTI total pembelian kedelai oleh anggota KOPTI untuk produksi tempe dan tahu pada 1996 sekitar 500.000 ton. Dari jumlah kebutuhan kedelai tersebut, 167.000 ton adalah pembelian sesuai alokasi dari BULOG/DOLOG dansisanya sekitar 233.000 ton dibeli oleh KOPTI maupun anggotanya sendiri di pasar bebas. Secara geografis sebagian besar dari KOPTI dan anggotanya tersebar di seluruh pulau Jawa. Di luar Jawa beberapa provinsi antara lain Sumsel, Lampung, Sumut, Jambi, Sulsel, dan Bali mempunyai banyak usaha kecil tempe dan tahu. Akan tetapi, tempe dan tahu adalah jenis makanan yang dikonsumsi terutama di pulau Jawa. Berdasarkan perkiraan tentang kebutuhan 500.000 ton kedelai tersebut, nilai hasil produksi tempe dan tahu dari anggota KOPTI melebihi Rp. 800 milyar pada tahun 1996. Potensi untuk mengembangkan hasil maupun nilai produksi tergantung pada persediaan kedelai dengan kualitasnya yangdipasok oleh BULOG maupun oleh para pedagang di pasar bebas. Para produsen makanan ternak memakai sebagian besar dari produksi kedelai para petani Indonesia. Selain produsen 
pakan, pabrik barang makanan skala besar, misalnya pabrik tahu, pabrik susu kedelai, pabrik taoco dan kecap membutuhkan kedelai dengan jumlah besar.

\section{Potensi Pasar Tempe dan Tahu di Daerah Kerja KOPTI}

Penilaian permintaan dan produksi tempe dan tahu di daerah kerja KOPTI dapat dilihat dari banyak laporan penilaian potensi perusahaan kecil tersebut di berbagai daerah, yangdibuat oleh PPUK Bank Indonesia. Dalam Model KPKT ini potensi pengembangan usaha tempe dan tahu di Kabupaten Bogor diambil sebagai contoh yang cukup representatif dan dapat menggambarkan potensi usaha para pengrajin tempe dan tahu.

Faktor faktor lainnya, selain kebutuhan kedelai yang mendorong permintaan tempe adalah pertumbuhan jumlah penduduk kedelai yang mendorong permintaan tempe yang sekitar 1,7 \% per tahun. Harga tempe dan tahu masih relatif lebih murah dibandingkan dengan sumber protein lainnya. Menurut pengurus INKOPTI ada peluang untuk mengekspor tempe ke negara lain, terutama ke Jepang. Faktor-faktor yang menghambat pengembangan usaha tempe dan tahu adalah terbatasnya kedelai di pasar dan pasokan dari BULOG pada periode bilamana permintaan tempe dan tahutinggi, misalnya pada saat pasokan ikan laut rendah (paceklik) atau pada Lebaran dan Hari Raya lainnya.

\section{Saluran Pemasaran serta Pengembangan Harga}

Saluran pasar berbeda untuk tempe dan tahu. Sebagian dari hasil produksi tempe di juallangsung kepada konsumen dipasar oleh para pengrajin dibantu anggota keluarga (+/- $90 \%$ dari penjualan tempe). Sisa hasil produksi tempe dipasarkan oleh para pengrajin kepada perusahaan catering, atau melalui tukang sayur di kawasan pemukiman. Sebagian besar dari hasil produksi tahu dipasarkan para pengrajin bekerja sama dengan jongkol, yaitu pedangang yang menyewa/mempunyai los di pasar atau melalui tukang sayur. Beberapa produsen tahu telah membuat hubungan bisnis kuat dengan usaha catering atau langsung dengan usaha besar lain, padat tenaga kerja, yang membutuhkan tahu dengan jumlah besar. Para pengrajin atau kelompok pengrajin tempe dan tahu mengangkut hasil produksinyakepada langganannya dengan sepeda motor milik sendiri atau dengan mobil box/pick-up milik KOPTI. Sebagian besar dari langganan anggota KOPTI berada di daerah kerja KOPTI. Persaingan antara para anggota KOPTI maupun dengan produsen tempe dan tahu lainnya, tidak terasa terlalu berat. Pengembangan usaha para pengrajin cukup stabil dan hasil produksi mereka dapat dijual secara kontinu tanpa gangguan yang berarti. Masalah fluktuasi harga beli serta kekurangan persedian kedelai diatasi oleh para produsen dengan mengubah kualitas dan ukuran produknya. Harga jual tahu dan tempe antara 1,6 s.d. 1,9 kali lebih tinggi dari harga pembelian kedelai, yaitu nilai tambah antara 35\% s.d. $47 \%$ kalau dihitung dari harga jual. Tingkat laba bervariasi sedikit dari musim ke musim setiap tahun. Sesudah panen saingan dari produsen tempe skala kecil yang belum menjadi anggota KOPTI cukup tingi dan tingkat laba menurun. Sebaliknya pada musim paceklik, penawaran ikan teratas tingkat laba cenderung naik. Perkembangan harga kedelai dari BULOG dan di pasar umum adalah indikator utama untuk menilai perkembangan harga tempe dan tahu. Pada periode 1989 sampai 1997 harge kedelai BULOG cukup stabil naik dari Rp.970,- per kilo menjadi Rp.1.052 ,- per kg pada 20 Agustus 1997. Harga kedelai di pasar bebas, agak sedikit lebih tinggi pada periode tersebut, yaitu naik dari Rp.1.018 menjadi Rp.1.120 per kilo.

\section{Kesimpulan tentang Aspek Pasar}

Permintaan dan produksi tempe dan tahu oleh anggota KOPTI tergantung pada pasokankedelai dari BULOG/DOLOG dimana KOPTI masih menerima subsidi sekitar Rp.50 per kilo. BULOG pada periode 10 tahun yang lalu sampai saat ini berhasil menstabilkan hargakedelai di Indonesia melalui impor kedelai dari luar negeri untuk memenuhi kebutuhankedelai domestik. Peranan BULOG sebagai pemasok kedelai menurun dari tahun ke tahun. Adakemungkinan monopoli BULOG akan dihapuskan. Tantangan untuk KOPTI melaluiINKOPTI menjadi importir/pemasok kedelai utama 
kepada anggotanya. INKOPTI/KOPTI harus mampu bersaing dengan pemasok kedelai lain di Indonesia, jika monopoli BULOG dihentikan. Permintaan tempe dan tahu cukup stabil dan naik antara $5 \%$ s.d. $10 \%$ per tahun. Para pengrajin mampu memasarkan hasil produksinya dengan harga yang menguntungkan para produsen. Tingkat laba bersih sesudah biaya transportasi dan biaya pemasaran sekitar 30\% di hitung dari harga jual. Untuk mengatasi fluktuasi harga maupun supply kedelai para produsen kecil tempe dan tahu menggunakan beberapa cara untuk menyesuaikan kualitas dan ukuran barang jadinya berdasarkan keadaan pasar kedelai pada tahun takwim. KOPTI melalui pembangunan Sentra PTT dapat membantu anggota peserta Sentra untuk memperluas jaringan pasar melalui kerja sama dengan usaha eksportir tempe maupun dengan institusi, sekolah, kantor, pabrik, dsb. Padat tenaga kerja sebagai konsumen.

\section{Aspek Produksi}

\section{Bahan Baku}

Untuk memproduksi tempe dan tahu digunakan bahan baku pokok yang sama, yaitu kedelai. Jenis kedelai terdiri atas 4 macam, kedelai kuning, kedelai hitam, kedelai coklat, dan kedelai hijau. Para pengrajin tempe biasanya memakai kedelai kuning sebagai bahan baku utama. Pengrajin tempe dan tahu biasanya menggunakan kedelai kuning, akan tetapi juga kedelai jenis lain, terutama kedelai hitam.

Kedelai berbiji besar bila bobot 100 bijinya lebih dari 13 gram, kedelai berbiji sedang bila bobot 100 bijinya antara 11-13 gram dan kedelai berbiji kecil bila bobot 100 bijinya antara 7-11 gram. Biji kedelai yang dipakai oleh para pengrajin untuk membuat tempeharus di kupas lebih dahulu dan biji kedelai tahu digiling sesudah biji kedelai direndam sekitar 7 jam lebih dahulu. Alat perontok biji kedelai dapat digerakkan dengan listrik maupun dengan pensettergantung persediaan listrik di Sentra dari PLN. Biaya listrik/solar dihitung dari jumlah biaya yang dibagi antara para pengrajin di Sentra produksi sesuai dengan rumus yang disetujui antara anggota Kelompok dengan KOPTI. Syarat mutu kedelai untuk memproduksi tempe dan tahu kualitas pertama adalah sebagai berikut: bebas dari sisa tanaman (kulit palang, potongan batang atau ranting, batu, kerikil, tanahatau biji-bijian); biji kedelai tidak luka atau bebas serangan hama dan penyakit; biji kedelai tidak memar; kulit biji kedelai tidak keriput.

\section{Bahan Pembantu Pembuatan Tempe}

Dalam pembuatan tempe dikenal beberapa macam ragi atau laru tempe digunakan dalam proses fermentasi yang menghasilkan tempe dengan kualitas tinggi. Secara tradisional para pengrajin membuat laru tempe dengan menggunakan tempe yang sudah jadi. Tempe tersebut diiris-iris tipis, dikeringkan, digiling menjadi bubuk halus dan hasilnya digunakan sebagai bahan inokulum dalam proses fermentasi. Laru lain yang sering dipakai adalah miselium kapang yang tumbuh di permukaan tempe. Salah satu macam laru dari Jawa Tengah disebut usar, dibuat dengan cara membiarkan spora kapang dari udara tumbuh pada kedelai matang, yang ditaruh antara dua lapis daun waru dan daun jati atau daun pisang bekas pembungkus tempe. Setelah itu laru diremas-remas lalu dicampurkanke dalam biji kedelai yang hendak di lakukan peragian. Untuk satu kilo kedelai diperkirakan membutuhkan 2 atau 3 lembar daun yang mengandung aru. Dalam praktik terjadi kesulitan memperoleh laru daun karena laru daun tidak dapat disimpan lama dan jumlah pemakaian sulit dipastikan. Oleh karena itu banyak pengrajin tempe membeli laru buatan berbentuk tepung di pasar. Bahan-bahan lain yang digunakan untuk membuat laru adalah beras, terigu, dan air bersih. Air bersih dipakai juga dalam proses produksi tempe untuk mencuci serta merebus biji kedelai sebelum proses fermentasi. Bahan pembungkus tempe adalah daun pisang maupun plastik berlubang-lubang. 


\section{Tenaga Kerja}

Tenaga kerja usaha kecil tempe dan tahu sebagian besar terdiri dari anggota keluarga para pemilik usaha tersebut, yaitu saudara dan anak para pemilik. Tingkat pendidikan umumnya relatif rendah sampai Sekolah Dasar. Sedangkan keterampilan yang di miliki diperoleh dari pengalaman setelah lama bekerja pada perusahaan kecil tempe dan tahu. Berdasarkan perhitungan tenaga kerja satu pengrajinmampu memproduksi $75 \mathrm{~kg}$ kedelai menjadi tempe sehari. Untuk memproduksi $100 \mathrm{~kg}$ tahu kebutuhan tenaga kerja dua orang pengrajin.

\section{Proses Produksi Tempe}

Tahapan proses produksi tempe adalah sbb. Pertama, biji kedelai yang telah dipilih/dibersihkan dari kotoran, dicuci dengan air PDAM atau air sumur yang bersih selama 1 jam. Kedua, setelah bersih kedelai direbus dalam air selama 2 jam. Kemudian direndam 12 jam dalam air panas/hangat bekas air perebusan denganmaksud supaya kedelai mengembang. Berikutnya direndam dalam air dingin selama 12 jam. Setelah 24 jam, kedelai dicuci/dikuliti (dikupas). Setelah dikupas, direbus untuk membunuh bakteri yang kemungkinan tumbuh selama perendaman. Kedelai diambil dari dandang, letakkan di atas tampah dan diratakan tipis-tipis. Biarkan dingin sampai permukaan keping kedelai kering dan airnya menetes habis. Kemudian dicampur dengan laru (ragi 2 \%) guna mempercepat/merangsang pertumbuhan jamur. Proses mencampur kedelai dengan ragi memakan waktu sekitar 20 menit. Tahap peragian (fermentasi) adalah kunci keberhasilan atau tidaknya membuat tempe kedelai. Lalu, bila campuran bahan fermentasi kedelai sudah rata, kemudian dicetak pada loyang atau cetakan kayu dengan lapisan plastik atau daun yang akhirnya dipakai sebagai pembungkus. Sebelumnya, plastik dilubangi/ditusuk-tusuk. Maksudnya ialah untuk memberi udara supaya jamur yang tumbuh berwarna putih. Proses percetakan/pembungkus memakan waktu 3 jam. Campuran kedelai yang telah dicetak dan diratakan permukaannya di hamparkan diatas rak dan kemudian ditutup selama 24 jam. Setelah 24 jam tutup dibuka dan didinginkan/diangin-anginkan selama 24 jam. Setelah ini campuran kedelai telah menjadi tempe siap jual. Agar tahan lama, tempe yang misalnya akan menjadi produk ekspor dapat dibekukan dan dikirim ke luar negeri di dalam peti kemas pendingin. Proses membekukantempu untuk ekspor adalah mula-mula tempe diiris-iris setebal 2-3 cm dan di-blanching direndam dalam air mendidih selama lima menit untuk mengaktifkan kapang dan enzim. Kemudian tempe dibungkus dengan plastik selofan dan dibekukan pada suhu 40 derajat Celcius sekitar 6 jam. Setelah beku disimpan pada suhu beku sekitar 20 derajat celcius selama 100 hari tanpa mengalami perubahan sifat penampak warna, bau, dan rasa.

\section{Sarana Produksi}

Sentra produksi tempe dan tahu sudah di bangun di beberapa wilayah dengan KOPTI sebagai pengembang. Di sentra yang sudah ada, masing-masing pengrajin mendapat rumah termasuk ruang produksi tempe dan tahu. Dengan kombinasi rumah tipe sederhana dengan ruang produksi para pengrajin hanya dapat melanjutkan produksi yang ada dengan alat produksi tradisional. Dalam Model KPKT ini KOPTI dapat membangun ruang produksi dan rumah pengrajin secara terpisah. Satu gedung produksi dapat dipakai oleh satu kelompok pengrajin. Gedung produksi harus lengkap dengan saluran air bersih, saluran listrik, gudang bahan baku, mesin penggiling kedelai serta prasarana lainnya yang melayani semua pengrajin. Di gedung produksi tersebut nanti para pengrajin dapat menetapkan alat produksi untuk membuat produk baru (diversifikasi) yaitu ada kemungkinan merubah cara produksi daricara pengrajin rumah tangga ke industri makanan.Tanah Sentra Produksi Tempe dan tahu milik KOPTI. Jumlah pengrajin yang ditetapkan sesuai dengan luas tanah maupun RUTR tentang penggunaan tanah sebagai sentra PTT. Masing-masing pengrajin dapat menerima hak atas sewa maupun membeli suatu bagian dari gedung produksi serta hak atas memakai dan menerima jasa dari seluruh prasarana yang disediakan di Sentra. Di samping itu masing-masing peserta Sentra memerlukan alat produksi milik sendiri. Rincian dari kebutuhan sarana serta prasarana produksi dicantumkan pada Aspek Keuangan dalam perhitungan Biaya Proyek. Dalam perhitungan tersebut 
biaya modal kerja juga diperhitungkan dengan jumlah sesuai dengan asumsi tentang hasil produksi tempe dan tahu.

\section{Aspek Keuangan}

Analisis Keuangan; analisis aspek keuangan Model KPKT Sentra Produsen Tempe dan tahu dihitung berdasarkan 4 model untuk kelompok pengrajin serta 2 model untuk usaha pengrajin tempe dan tahu perorangan sbb. Proyek Sentra Tempe milik 20 pengrajin yang masing-masing membeli Strata, yaitu hak guna sebagian ruang produksi. Proyek Sentra Tempe milik KOPTI yang disewakan kepada 20 anggota pengrajintempe, masing-masing dengan ruang produksi sama besar. Proyek Sentra Tahu milik 10 pengrajin yang membeli Strata. Proyek Sentra Tahu milik KOPTI yang disewakan kepada 10 anggota pengrajin tahu. Proyek pengrajin Tempe perorangan kapasitas produksi $75 \mathrm{~kg}$ kedelai/hari tempat produksi di luar Sentra. Proyek pengrajin Tahu perorangan kapasitas produksi 100 kg kedelai/hari tempat produksi diluar sentra.

Jumlah pengrajin anggota kelompok tempe dan tahu di suatu Sentra dapat berbeda dari satu daerah dengan daerah lain, sesuai dengan luas tanah KOPTI serta, kelompok pengrajinyang telah ada di KOPTI bersangkutan. Akan tetapi, satu bangunan produksi harus mampu menampung 10 atau lebih pengrajin. Jumlah pengrajin tertinggi dalam salah satu gedung produksi tidak dihitung. Tim peneliti model PKT ini memperkirakan secara optimal, satu gedung produksi dapat menampung antara 10 s.d. 40 pengrajin. Luasnya gedung produksi tersebut disesuaikan berdasarkan jumlah pengrajin/penghuni. Masing-masing pengrajin tempe harus mampu memproduksi $50 \mathrm{~kg}$ kedelai atau lebih per hari, dan pengusaha tahu harus mampu memproduksi $100 \mathrm{~kg}$ kedelai atau lebih per hari.

Perhitungan biaya investasi maupun biaya modal kerja serta asumsi-asumsi tentang masingmasing model dapat dilihat pada lampiran berikut. Perlu diinformasikan bahwa yang dimaksud dengan Sentra Produsen Tempe dan Tahu adalah betul-betul fasilitas untuk produksi, sedangkan fasilitas perumahan diusulkan untuk dibiayai dengan skema kredit KPR RSS maupun KPR-RSS. Skema kredit yang dapat membiayai usaha tempe dan tahu model kelompok maupun usaha perorangan, yaitu usaha pengrajin KOPTI adalah Kredit kepada Koperasi Primer untuk Anggota (KKPA) atau Kredit Usaha Kecil (KUK).

\section{Peluang Pembiayaan dan Pola Jaminan Kredit Bank}

\section{Potensi untuk membiayai KPKT - Sentra Produsen Tempe dan Tahu}

Sesuai data tentang jumlah KOPTI dan jumlah pengrajin tempe dan tahu kebutuhan kredit bank dapat di hitung berdasarkan asumsi-asumsi sebagai berikut. 1) Sentra Produsen Tempe dan tahu di bangun oleh KOPTI diatas tanah KOPTI sendiri. 2) KOPTI telah memperoleh persetujuan serta ijin-ijin lengkap dari instansi Pemdamaupun Kandepkop \& PPK dan memenuhi semua persyaratan sah untuk membangundan mengelola Senta. 3) Biaya Konstruksi serta pemilihan pemborong untuk membangun sarana dan prasaranadi Sentra di tentukan Pengurus KOPTI atas perancanaan gambar dan bestek yang lengkapdan nyata serta dasar penawaran umum (public tender)

\section{Potensi Pemberian Kredit Bank}

Dari jumlah KOPTI di Indonesia, yaitu 144 unit dengan 27.000 anggota pengrajin tempe serta 10.000 anggota pengrajin tahu. Tim peneliti Model KPKT ini, menilai sekitar 40 \%dari KOPTI cukup layak untuk dibiayai langsung oleh bank, yaitu KOPTI yang mempunyai tanah serta anggota yang cukup kuat. Sedangkan sebagian dari sisa anggota serta KOPTI yang dapat dibiayai sesudah dibina pada periode tertentu oleh bank dan instansi lain. 
Bank-bank pemberi kredit dapat memakai angsuran pokok tahun, dengan jumlah sekitar Rp.5 milyar dihitung dari total kebutuhan kredit di atas, ditambah Rp.3 s.d. 5 milyar untuk membiayai sekitar 30 Sentra Produsen Tempe dan tahu setiap tahun mendatang. Oleh karena KOPTI serta para anggota kelompok layak untuk menerima KKUD serta KKPA, bank pemberi kredit dapat mengajukan permohonan atas kredit koperasi tersebut ke Bank Indonesia berdasarkan jumlah KOPTI maupun Sentra yang direncanakan untuk dibiayai setiap tahun. Form 2 yaitu Formulir Penilaian Proyek Kredit Koperasi Primer untuk Anggotanya (KKPA) dilampirkan.

\section{Jenis Jaminan Kredit Bank}

\section{Agunan Pokok}

Agunan pokok yang menjamin pinjaman investasi dari bank adalah tanah serta bangunan. Karena KOPTI mempunyai hak milik atau hak guna atas tanah, kredit yang diberi oleh bank hanya akan membiayai sarana serta prasarana produksi di Sentra. Agunan pokok yang diberikan yang menjaminkan pinjaman modal kerja bank kepada para pengrajin adalah barang yang dibiayai yaitu persediaan kedelai dan barang jadi. Nilai barang agunantersebut dianggap kurang.

\section{Agunan Tambahan}

Agunan tambahan adalah kekayaan KOPTI sendiri maupun modal milik para peserta pengrajin yang dibiayai. Dari beberapa barang dan model KOPTI yang boleh menjamin kredit bank Tim mengusulkan sebagai berikut: tanah dan bangungan KOPTI serta Sentra yang dibiayai bank; aktiva , yaitu tabungan dan deposito wajib KOPTI titipkan di BULOG/DOLOG.Tabungan tersebut memerlukan persetujuan Depkop \& PPK jika dana tersebut akanmenjamin kredit bank ke KOPTI maupun anggotanya; tabungan anggota KOPTI yang dibiayai dapat menjadi tabungan beku di bank pemberi kredit; tanggung renteng dari anggota kelompok di Sentra untuk menjaminkan pembayarantunggakan pokok maupun bunga dari satu atau lebih anggota kelompok; asuransi kredit di Perum PKK, Askrindo atau lembaga asuransi kredit lain,misalnya USAID; para pengrajin di Sentra akan membayar setoran pinjaman bank sebagai setoran harian.

Di samping mengikat barang agunan tersebut yang menjamin pinjaman bank, KOPTI diminta untuk menyusun Surat Kuasa untuk memasang hak tanggungan serta hak untuk menjual atas tanah dan bangunan serta hak tagihan atas cessie maupun tabungan/deposito yang menjamin kredit bank, khususnya pinjaman modal kerja. Contoh Nota Kesepakatan yang mengatur hubungan bisnis serta hak dan kewajiban antara KOPTI dengan Kelompok anggotanya di Sentra Produsen Tempe dan Tahu dilampirkan.

\section{SIMPULAN}

Arah perkembangan ekonomi nasional ditandai dengan surutnya sektor pertanian dan membesarnya sektor industri dan jasa. Tumbuhnya industri modern di perkotaanmerupakan kecendrungan wajar dalam sejarah perkembangan suatu negara. Koperasi saatini tertinggal di bandingkan dengan BUMS dan BUMN karena terbatasnya modal, SDM serta kurangnya wiraswasta koperasi. Akan tetapi, beberapa jenis makanan tradisional khas Indonesia yang dibuat oleh pengrajin rumah tangga, dapat diproduksi secara industri skala kecil, bilamana industri dikembangkan bersama antara Koperasi dengan kelompok anggotanya. Pengembangan Sentra Produsen Tempe dan Tahu melalui Program Kemitraan Terpadu oleh KOPTI sebagai perusahaan inti dengan kelompok pengrajin tempe dan tahu, yaitu para anggota KOPTI adalah kegiatan modernisasi usaha kecil tempe dan tahu menjadi usaha industri makanan mandiri. Pembangunan Sentra PTT diharapkan dapat menjadi salah 
satu Program Kemitraan Nasional yang melibatkan bank pemberi KUK/KKPA, instansi Pemda yang menyediakan lokasi kepada Sentra PTT serta BULOG sebagai pemasok kedelai terbesar kepada para mitra usaha, yaitu KOPTI dan kelompok anggota KOPTI. Melihat dari Sentra PTT antara lain sebagai berikut. Pertama, membantu Pemda dan para pengrajin relokasi usaha tempe ke lokasi yang sesuaidengan RUTR. Kedua, memberi peluang bisnis yang baik kepada KOPTI maupun Sentra PTT. Ketiga, mengatasi dampak negatif terhadap rona lingkungan di daerah Sentra PTT, karenasetiap sentra PTT di lengkapi dengan prasarana pengelolaan limbah. Keempat, meningkatkan tingkat hygienitas dan keamanan produksi tempe dan tahu melalui persediaan air bersih serta sarana dan prasarana produksi yang sesuai dengan peraturanindustri makanan. Dan kelima, memudahkan bank dalam pengawasan dan pembinaan masalah.

\section{Saran}

Proses modernisasi usaha kecil pengrajin tempe dan tahu yang tersebar terutama di kota besar di pulau Jawa di laksanakan oleh KOPTI melalui pengembangan Sentra PTT. Dalam Model KPKT ini, ada enam pola usaha kecil tempe dan tahu yang dikembangkan untuk dibiayai dengan kredit usaha kecil, misalnya dengan KKPA.

\section{Saran kepada Bank}

Pertama, Sentra PTT dikembangkan oleh KOPTI di atas tanahnya dengan mempertimbangkanketentuan RUTR dan mendapat ijin dari instansi berwenang. Kedua, KOPTI menyerahkan agunan tambahan sesuai dengan persyaratan bank pemberikredit, termasuk Surat Kuasa tanah, sarana dan prasarana produksi di Sentra PTT yangdibiayai oleh Bank. Ketiga, KOPTI bekerja sama dengan bank untuk menggunakan kredit bank sesuai dengankebutuhan sentra PTT. Dalam hal ini KOPTI berlaku sebagai agen pelaksanaan kredit (executing agent), pengembalian kredit dari anggota dilaksanakan melalui setoran harianoleh para debitur (anggotanya).

\section{Saran kepada Instansi Pembina KOPTI termasuk PEMDA setempat}

Pada tingkat Nasional disarankan untuk membentuk Tim Khusus Sentra PTT yang membantu KOPTI dengan: perolehan izin dari instansi terkait; jaminan tambahan untuk menjamin kredit bank sesuai dengan kondisi Sentra PTTsetempat misalnya memakai sebagian setoran wajib KOPTI di BUKOPIN atas BULOG sebagai dana penjaminan (guarantee fund) dan akses ke asuransi kredit Sentra PTT secara Nasional dari PERUM PKK atau Askrindo; memperkuat fungsi dan peranan INKOPTI sebagai usaha pemasok kedelai melalui kerja sama dengan BULOG, BUKOPIN serta sejumlah KOPTI di Indonesia.

Pada tingkat II membina KOPTI serta kelompok anggotanya peserta Sentra PTT di bidang pengelolaan dan peningkatan sistem logistik pengadaan kedelai; mempertinggi kualitas, sanitasi serta hasil produksi tempe dan tahu di Sentra PTT melalui pemanfaatan sarana dan prasarana produksi tepat guna; membantu para pengusaha kecil melakukan diversikasi hasil produksi dengan produk yang mempunyai nilai tinggi serta teknologi yang sesuai dengan kemampuan KOPTIserta anggotanya; meningkatkan peluang pasar bagi anggota KOPTI dengan cara memperluas jaringan bisnis dengan perusahaan besar padat tenaga kerja, usaha catering maupun para eksportir tempe 


\section{DAFTAR PUSTAKA}

Badan Standardisasi Nasional. (2012). Diakses dari www.bsn.go.id.

Indonesian Institute of Scieces. (2002). Diakses dari www.lipi.go.id.

Koperasi Produsen Tempe Tahu Indonesia (KOPTI)

Rayandi, D. S. (2008). Panduan Wirausaha Tempe. Yogyakarta: Media Pressindo.

Shurtleff, W. \& Aoyagi, A. (2001). The Book of Tempeh. California, USA: Ten Speed Press. 